\title{
Determining the climate impact of food for use in a climate tax-design of a consistent and transparent model
}

\author{
Emma Moberg ${ }^{1}$ (D) $\cdot$ Maria Walker Andersson ${ }^{2} \cdot$ Sarah Säll $^{3} \cdot$ Per-Anders Hansson $^{1} \cdot$ Elin Röös ${ }^{1}$
}

Received: 29 May 2018 / Accepted: 16 February 2019 / Published online: 8 March 2019

(C) The Author(s) 2019

\begin{abstract}
Purpose The aim of this study was to determine transparent food carbon footprint values for use in a climate tax, using a consistent methodology across the taxed food products and taking into account the need for such a tax to be administratively simple and accepted by affected stakeholders.

Methods A method based on Life Cycle Assessment following the ISO 14067 standard was developed for establishing simplified, yet consistent and transparent, datasets on the carbon footprint of food, for use as a base in a climate tax on food. Several sensitivity analyses were carried out to test the effects of inevitable methodological choices on the carbon footprint of different foods. The choices were then discussed in relation to taxation of food. The methodological choices included in the sensitivity analyses were different approaches to system boundaries, how to account for soil carbon changes and how to weigh greenhouse gases (GHGs).

Results and discussion The results on the carbon footprint of food calculated with the suggested method are in line with earlier findings in the field, with animal products, especially beef, showing a substantially higher value than most plant-based foods. Regarding choice of system boundaries for using the values in a tax, it is of particular importance to target emissions from biological processes, as these are currently untaxed. This would also be administratively simpler but less acceptable as large emission sources especially for imported products and greenhouse grown vegetables would not be included. Modelling emissions from soil carbon changes using a site-dependent method can be an advantage to obtain results in line with empirical data. Using Global Warming Potential over 100 years to weigh GHGs would be most in line with current climate reporting, which is an advantage for the consistency and acceptability of a tax.

Conclusions Ultimately, how taxes are set is a political decision, but food carbon footprint values determined with a consistent and simplified methodology are required in the process. This study presents carbon footprint values established using such method and provides valuable insights into how methodological choices affect the results of climate impact values and the implications for taxation.
\end{abstract}

Keywords Carbon footprint $\cdot$ Climate tax $\cdot$ Food consumption $\cdot$ Life Cycle Assessment

\section{Responsible editor: Matthias Finkbeiner}

Electronic supplementary material The online version of this article (https://doi.org/10.1007/s11367-019-01597-8) contains supplementary material, which is available to authorized users.

Emma Moberg

emma.moberg@slu.se

1 Department of Energy and Technology, Swedish University of Agricultural Sciences, 75007 Uppsala, Sweden

2 Department of Earth Sciences, Uppsala University, 752 36 Uppsala, Sweden

3 Department of Economics, Swedish University of Agricultural Sciences, 75007 Uppsala, Sweden

\section{Introduction}

The current food system is a major contributor to climate change, causing 19-29\% of total global greenhouse gas (GHG) emissions (Vermeulen et al. 2012). Animal-based products generally have a substantially larger climate impact than plant-based foods (Nijdam et al. 2012; Clune et al. 2017), so shifting away from animal-based products has been identified as an effective approach to achieve significant reductions in GHG emissions from the food sector (Springmann et al. 2018; Bryngelsson et al. 2016). However, changing people's consumption patterns is challenging (Hartmann and Siegrist 2017) and voluntary actions alone are probably not sufficient 
to reach climate targets (Garnett et al. 2015). Public financial policy, specifically a climate tax on food consumption, has therefore been proposed by non-government organisations (NGOs) and public authorities in countries such as Sweden (Lööv et al. 2013; SSNC 2015). Effects of such a tax have also been modelled in the scientific literature. For example, Säll and Gren (2015) found that emissions from the Swedish livestock sector could be reduced by $12 \%$ with a Swedish tax on animal products, while modelling of global pricing of food by Springmann et al. (2016) showed potential to reduce global food-related GHGs by $9 \%$. A tax on consumption rather than production has been promoted, as such a tax has the advantage that domestic and imported products are equally affected, hence reducing the risk of emission leakage from moving production to other countries (Säll and Gren 2015; Van Doorslaer et al. 2015).

A climate tax on food consumption would be an example of an excise duty which Sweden, amongst other countries, have implemented already in several areas, e.g. on emissions of carbon dioxide $\left(\mathrm{CO}_{2}\right)$ from energy use and on tobacco and alcohol. Similar to how current excise duties are managed, an excise tax on food would probably be implemented in a tax system separate to other consumption taxes such as the valueadded tax (VAT) (Swedish Tax Agency n.d.). In theory, an ideal cost-efficient tax on GHG emissions would be set at the marginal damage costs associated with emissions per unit (Pigou 1920). With respect to climate taxing food consumption, the tax on certain food products would then be determined by (1) the amount of emissions caused by the production and use of the food and (2) the marginal damage cost of the emissions. In this study, we investigated aspects involved in determining point (1), i.e. determining the carbon footprint of the food. The carbon footprint of a product is synonymous with a Life Cycle Assessment (LCA) that takes no other environmental impact category but climate change into consideration (ISO 2013).

Establishing the carbon footprint of foods involves a number of methodological choices, which can have a large impact on the output (Notarnicola et al. 2017). Therefore, before the implementation of a climate tax, supporting data on the climate impact of different foods must be established using a consistent methodology across all taxed food products. The datasets of the climate impact should reflect as correctly as possible the actual emissions from the life cycle of the food products on the Swedish market, in order for the tax to be costefficient and accepted by affected stakeholders. At the same time, the method used to establish the datasets has to be transparent in order to be administratively simple and easy to update and apply.

There is a large body of literature on the carbon footprint of food, ranging from assessments of specific food products to comprehensive reviews (Clune et al. 2017; Nijdam et al. 2012). Further, a number of databases exist that compile data on the climate impact of food on the global market, for example the World Food LCA database (Nemecek et al. 2015) and the Agri-footprint database (Durlinger et al. 2017), and on national level, for example the French AGRIBALYSE (Koch and Salou 2016) and the Swedish RISE database (Florén et al. 2015). However, none of these offer datasets suitable for being used in taxation, since no database or data in review studies is simultaneously (1) consistent in the methodology used across all food products, (2) representative for foods sold on the Swedish market and (3) sufficiently transparent.

The aim of the present study was therefore to determine transparent food carbon footprint values for use in a climate tax, using a consistent methodology across the taxed food products and taking into account the need for a tax to be administratively simple and accepted by affected stakeholders. To this end, a model for establishing consistent and transparent datasets on the climate impact of foods, to use as a base for taxation, was developed. To test how different unavoidable methodological choices affected the estimated climate impact of foods, various sensitivity analyses were conducted. Further, the implications of the choices for the values to be used in taxation were discussed, i.e. how the choices affected the criterion of implementing a cost-efficient, accepted and administratively feasible tax.

\section{Background}

\subsection{Greenhouse gas emissions from the food system and current taxation on these}

In comparison with the transport and energy sectors where emissions of GHGs are dominated by fossil fuel related $\mathrm{CO}_{2}$, the emissions generated during the life cycle of foods include substantial amounts of methane $\left(\mathrm{CH}_{4}\right)$ and nitrous oxide $\left(\mathrm{N}_{2} \mathrm{O}\right)$. Emissions of $\mathrm{CH}_{4}$ mainly arise from feed digestion in ruminants, while the majority of the $\mathrm{N}_{2} \mathrm{O}$ emitted originates from fertilised soils. Another important source of foodrelated GHGs is emissions of $\mathrm{CO}_{2}$ due to soil carbon changes resulting from changes in land management and land use change (LUC), i.e. transformation of land from one use to another (Goglio et al. 2015). Additional emissions arise in the production of inputs to agriculture and in processing, refrigeration, packaging, storage and transportation of food commodities. In addition, use of refrigerants, e.g. for storing wild-caught fish on vessels, causes emissions of the hydrochlorofluorocarbon R22 (HCFC-22) (Ziegler et al. 2013).

Carbon taxes or emission trading systems (ETS) covering $13 \%$ of global GHG emissions have already been implemented in 40 countries, including Sweden (Författningssamling 1994; World Bank et al. 2016). These carbon-pricing mechanisms cover some of the $\mathrm{CO}_{2}$ emissions associated with food 
production, namely those from the use of electricity and fuels. However, emissions of $\mathrm{CH}_{4}$ and $\mathrm{N}_{2} \mathrm{O}$ are currently untaxed except for $\mathrm{N}_{2} \mathrm{O}$ emissions from mineral fertiliser production in the European Union (EU), which are included in the EU ETS. The compound HCFC-22 is not subject to any tax, but its use is now banned under an EU directive (European Parliament and Cote 2014) and it is thus currently being phased out. To the best of our knowledge, specific climate taxes on food have not yet been levied in any country.

\subsection{Conditions for optimal tax levels}

To obtain an ideal cost-efficient tax on GHG emissions, all emissions, irrespective of source, should be priced at the same level, as mitigation options will then be implemented in sectors where emissions can be reduced at the lowest cost (e.g. Baumol and Oates 1988). Therefore, taxes should ideally as closely as possible reflect the varying emissions generated when producing different products using different technologies. In the case of food, this would include differentiating between, e.g. vegetables grown in energy-demanding heated greenhouses and those grown in open fields and between different energy sources (e.g. fossil or renewable energy), in order to correctly reflect the true emissions from production. In addition, double taxation should be avoided by considering existing carbon taxes from the use of electricity and fuels in food production when establishing a tax on different food groups (Gren et al. 2019).

However, due to the high number of different food products available on the globalised food market of industrialised countries and the rapid development of new products, it is unlikely that a climate tax on food in practice could be based on detailed LCAs on each and every food product on the market. The cost of calculating and verifying the climate impact of all individual products would be unreasonably high (e.g. The Guardian 2012). For the same reasons, it is unlikely that differentiated charges for different technologies used during production can be implemented. Although it is possible to use national statistics to establish national averages for different foods from different countries, differentiating taxes based on country of origin of the product would not be a viable option, as that would likely violate the 'most-favoured nation' principle of the World Trade Organization (WTO). This principle states that members of the WTO must apply the same trading rules to all other WTO members, so differentiated tax rates for different countries would risk being discriminatory (Bähr 2015). Based on this, it would probably be necessary to base a tax on broader, more aggregated food groups.

It is important to also note that excise duties seldom are set so that they reflect the true externalities. Rather, they are a result of political negotiations including other considerations of the tax, such as being administratively simple (Government of Sweden 2009).

\section{Methods}

\subsection{General model choices and input data used in the modelling}

The proposed method uses a top-down approach to account for the GHG emissions associated with production of food from different countries available on the Swedish market. These are then aggregated based on import statistics to establish an average value for food sold on the Swedish market (Fig. 1). This approach enables the use of primary sitespecific data for the most influential parameters in the calculations, such as yield levels and slaughter statistics, which are easily available in the form of datasets on national level for many countries (e.g. in national official statistics, National Inventory Reporting or national guidelines and reports from advisory services) (Fig. 2). This means that input data on the most influential parameters can easily be updated on a regular basis and that the results reflect the average carbon footprint of that food group on the Swedish market.

While primary site-specific data are often readily available for Sweden and many European countries, there are also cases when such data is not available for certain countries or food groups, e.g. fruits imported from South America. Data is then collected by the following order of prioritisation based on availability: data from the World Food LCA Database (Nemecek et al. 2015), peerreviewed LCA studies and LCA reports. The World Food LCA Database is considered suitable, as it is available through the Ecoinvent database version 3.5 (Ecoinvent Centre 2018) and covers a variety of food products on the global market and offers access to the input data. Note however that using these data sources is a fallback solution that is used for food groups where primary data is not available. With future improvements in data availability, this can easily be changed.

For emission sources that are of less importance to the final results (e.g. packaging and electricity use in processing), standard values based on both primary and secondary literature data sources (carefully chosen to be representative for foods on the Swedish market) are used, which can simplify maintenance of the datasets. To further simplify maintenance, processes making a minor contribution to the final results (seed and seedling production, pesticide and mineral phosphorus and potassium fertiliser production, energy use for storage at wholesaler and retailer) are excluded. All input data to the model and further justifications for data choices are presented in the Electronic Supplementary Material.

\subsection{Standardisation applied in the assessment}

To align the method as far as possible with existing efforts to make LCA calculations consistent in the LCA community, thereby maximising acceptability and trust, the method follows the ISO 14067 carbon footprint standard (ISO 2013) for everything 


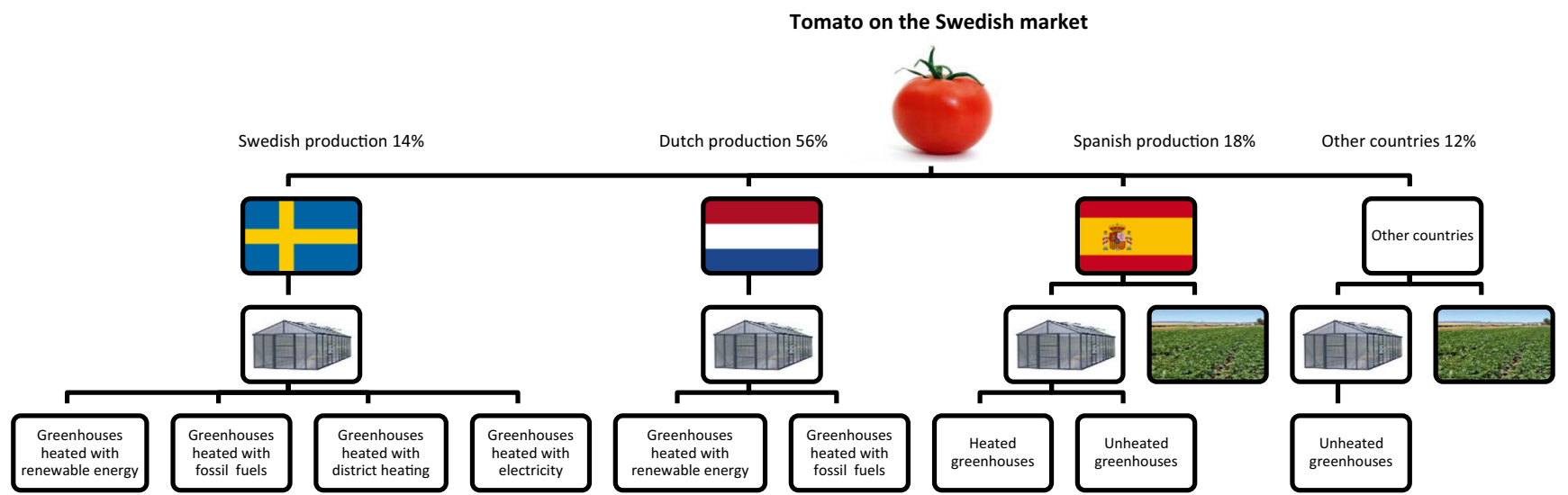

Fig. 1 Illustration of how the carbon footprint of a tomato on the Swedish market is assessed, i.e. aggregated from different countries using different production techniques

except the exclusion of biogenic carbon uptake, as this carbon is released to the atmosphere when the food is consumed.

There have been several initiatives to standardise calculation of the climate impact of products and foods in particular (e.g. BSI 2008, 2012; Food SCP RT 2013; European Commission 2016). However, none of the available standards are sufficiently specific and detailed to be used in the present application without modification. For example, most existing standards are based on the use of product category rules (PCR), which are sets of specific rules applied to different products (e.g. PCRs for beer, olive oil and meat have been developed within the EU's product environmental footprint (PEF) initiative (European Commission 2016)). For taxation, a method is needed that is consistent across food groups, not just within food groups.

\subsection{Methodological choices in the modelling}

\subsubsection{Attributional LCA modelling}

The method uses an attributional LCA (ALCA) approach, where GHG emissions directly associated with the production steps are accounted for.

Another approach in LCA is consequential LCA (CLCA), which accounts for the change in environmental impact as a consequence of a changing market using marginal data (Finnveden et al. 2009). With the CLCA approach, emissions caused by producing a specific food item on the margin are calculated, which could be considered more in line with economic theory on taxing marginal emissions. However, such an approach would require knowledge of the marginal technologies in food production, i.e. where, and with what technologies, the production of a certain food group would increase or decrease as a consequence of a marginal market change. This is possible to estimate using, e.g. economic equilibrium models (e.g. Kløverpris et al. 2010), but the outcomes of these models depend on many assumptions and are therefore highly uncertain, difficult for non-experts to interpret and costly to update.
Therefore, as Brandão et al. (2014) suggest, ALCA methodology can be considered more suitable for use in policy for the implementation of a decision to move towards a policy goal such as changed consumption patterns of food.

\subsubsection{Reference unit}

With the proposed method, the climate impact is assessed based on the reference unit of $1 \mathrm{~kg}$ of product (litre for drinks and oils).

Here we avoid the use of the term 'functional unit' not to give the impression that different food groups are functionally equal. Comparing foods per unit mass in LCA has been criticised for failing to consider the function of foods and alternative ways to account for the function have therefore been suggested (Notarnicola et al. 2017). Alternatives are commonly based on the nutritional quality of the foods, e.g. by use of energy content (kilocalories), or single nutrients, e.g. kg of protein, in the reference unit. Such units may be suitable when comparing the climate impact within one food category providing the same function (e.g. using per $\mathrm{kg}$ of protein for proteinrich foods such as meat, dairy, egg, legumes and cereals), but is less suitable when comparing products from different food groups. For example, using energy content as the reference unit would not capture the benefits of fruit and vegetables, which are low in energy but dense in fibre and important micronutrients.

Instead, to reflect the overall nutritional quality of foods, a 'nutrient index' can be used (Hallström et al. 2018). The basis of most nutrient indices is to consider the content of a range of nutrients in food products in relation to the recommended daily intake of these nutrients. Several models have been developed which differ, e.g. with respect to the nutrients included, daily recommended values and the algorithm used to compute the index (Drewnowski 2009). Although it would be possible to relate the climate impact of foods to their nutritional quality, the design of nutrient indices and the combined values would rely on many choices and limit the transparency of datasets, which potentially could reduce understanding and acceptance of a tax. 
Fig. 2 Conceptual model of the method suggested for calculating the carbon footprint of foods on the Swedish market for use in a climate tax of food
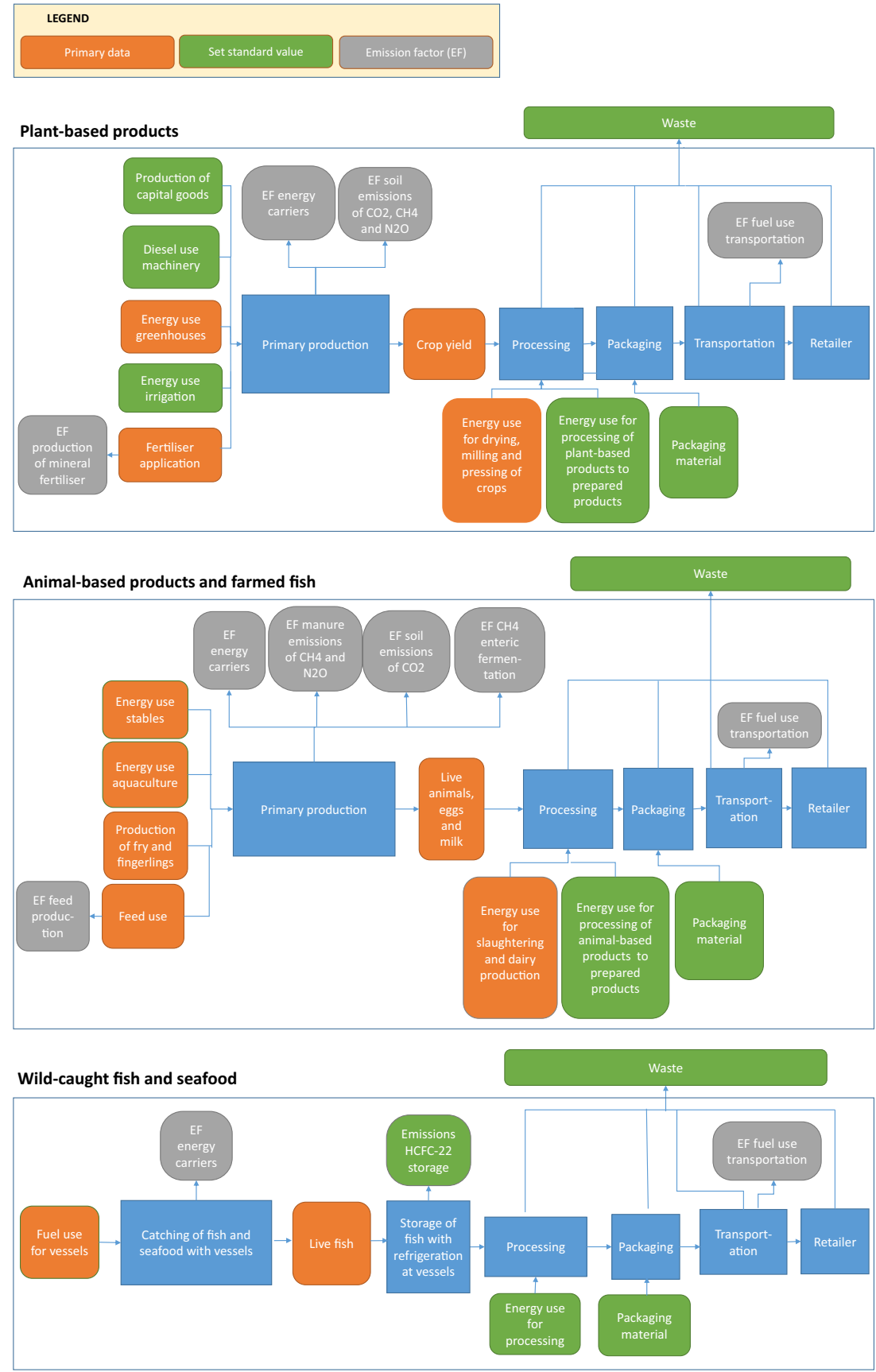

Further, using a joint climate-nutrition dataset of foods for taxation would limit the cost efficiency of a tax, as there is no clear relationship to the damage cost of these aspects combined. Rather, using $1 \mathrm{~kg}$ as the reference unit is likely the only valid reference unit on which to base a tax as the emissions to be taxed should be directly related to the amount of food purchased.

\subsubsection{Allocation method}

Economic allocation is used in the proposed method to allocate emissions from joint production systems across different products (e.g. milk and meat from dairy production).
Other strategies are possible, such as physical allocation based e.g. on mass or energy content of each by-product. Physical allocation is used in the Renewable Energy Directive (RED) of the EU (European Union 2009), based on the energy content in fuels. This is a viable option for the specific case of fuels, but when considering taxes for different categories of food providing different functions, it is difficult to decide upon a suitable physical property (compare discussion of the reference unit in the 'Reference unit' section). Instead, economic allocation can be considered more suitable as it can be used across products, which is important for consistency in the methodology. Due to fluctuating market prices, economic allocation factors should 
preferably be calculated as an average of a longer time period in order to be robust.

\subsubsection{System boundary}

Our proposed method uses a system boundary from cradle to Swedish retail, i.e. accounting for emissions arising from the production of input materials, primary production, processing, packaging, transportation and food losses in the different stages until the food is available on the Swedish market (losses are included for the retail stage too) (Fig. 3).

The full life cycle of a food product also includes processes after retail, but many of these post-retail emissions are already covered by the Swedish $\mathrm{CO}_{2}$ tax (Fig. 3). It can therefore be argued that these emissions should be excluded from a climate tax on food, as double taxation of products should be avoided for a Pigovian tax to be cost-efficient (Gren et al. 2019). The same applies to energy use in processing, packaging, storage and transport, as these are covered by the national $\mathrm{CO}_{2}$ tax, although there are partial reductions in the tax for some sectors. On the other hand, international transport is not always taxed, certainly not sea or air transport, and energy use in food production or production of packaging material abroad may not be. Hence, we choose to include these life cycle steps in the tax scheme in order to reflect the full carbon footprint up to retailer.

How to administer a tax, especially the point in the food system at which the tax should be paid, may also influence where and how system boundaries are drawn. Current excise taxes, e.g. on tobacco and alcohol, are paid by the party that produces or imports the product, so supermarkets, restaurants, etc. buy the already taxed product (Swedish Tax Agency n.d.). Hence, tax payments are made by fewer companies and are therefore easier to control and administer (Statistics Sweden 2018). Applying the same approach to the food sector would require taxes to be paid by major producers of food commodities, e.g. dairy companies, mills and slaughterhouses (Fig. 3). With such a system, a cradle-to-farm gate approach would be more suitable for a climate tax on food. The post-farm gate emissions, which are mainly energy-related, would then need to be covered by a $\mathrm{CO}_{2}$ tax on energy, which is already in place in Sweden and many other European countries.

Another, simpler, approach could be to limit the tax to emissions from the agricultural sector only as defined by the IPCC (Smith et al. 2014), i.e. including only emissions from biological processes giving rise to emissions of $\mathrm{CO}_{2}, \mathrm{CH}_{4}$ and $\mathrm{N}_{2} \mathrm{O}$ (emissions from soils, enteric fermentation and manure management). These emissions are currently untaxed, while energy and transport-related emissions are (or should be) covered by $\mathrm{CO}_{2}$ taxes. To test how the choice of system boundary affected the modelling outcome, a sensitivity analysis was carried out using different approaches (see 'Discussion' section).

\subsubsection{Accounting for carbon changes in soils}

Our proposed method includes soil carbon changes by using a simplified strategy based on the Introductory Carbon Balance Model (ICBM) (Andrén and Kätterer 1997).

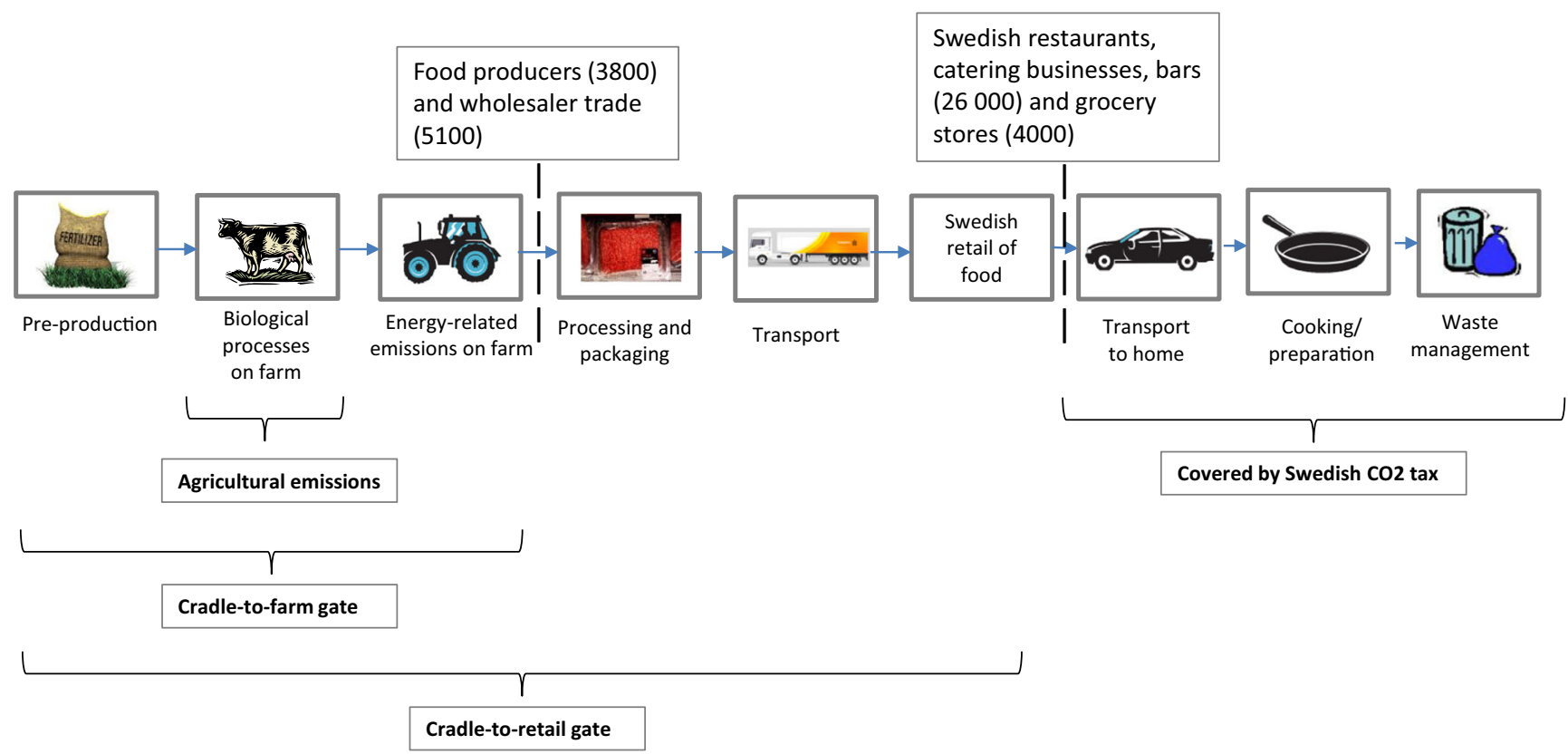

Fig. 3 System boundaries according to the point of administration of a tax, with approximate number of actors in each stage in brackets. Data retrieved from Statistics Sweden (2018) and Svensk Dagligvaruhandel (2018). Pictures used with permission from Viktor Wrange and Fredrik Saarkoppel 
Changes in soil carbon can have a large impact on the climate impact of food and other biomass-based products. Emissions due to soil carbon changes are currently untaxed and sequestration of carbon in soils is not financially rewarded in Sweden. Soil carbon changes are included in other policies, e.g. the RED (European Union 2009), and schemes to pay farmers for the carbon sequestered in soils have been implemented in countries such as Australia (Australian Government n.d.).

According to the ISO 14067 standard, changes in soil carbon should be included in carbon footprint assessments based on an internationally recognised method such as the IPCC Guidelines for National Greenhouse Gas Inventories (NIR) or on a national approach based on a verified study (ISO 2013). The ICBM is used in the Swedish NIR (SEPA 2017) and accounts for the emissions/sequestration in mineral soils based on the driving variables of climate and carbon input to soils from, e.g. manure and crop residues. We used this method to assess the 'soil carbon change potential', i.e. the amount the soil would sequester or loose until it reaches steady state, from cultivation of cereals, legumes, oilseed rape, root vegetables and grass-clover ley. Cultivation of these crops leads to very different carbon inputs to soil (carbon input being a main determinant of soil carbon changes). This potential change was compared with the current average carbon content in Swedish soils as a reference (100 t C per ha; Poeplau et al. 2015). Further, the change was annualised over 100 years and divided by the annual yield, from which an estimate was obtained of the potential annual $\mathrm{CO}_{2}$ emissions/sequestration caused by soil carbon changes per $\mathrm{kg}$ of crop (Electronic Supplementary Material). As the ICBM is mostly used in Sweden, a more general approach to account for soil carbon changes (IPCC 2006) was tested in a sensitivity analysis ('Accounting for carbon changes in soils' section).

\subsubsection{Accounting for emissions due to land use change}

LUC emissions for soybean and oil palm in animal feed are included in the proposed method using emissions factors from Henders et al. (2015).

Emissions from LUC arise when land is transformed from one use to another, e.g. from forest to cropland (Edenhofer et al. 2011), and can contribute considerably to the carbon footprint of food (e.g. Flysjö et al. 2012). Deforestation in South America and Asia, driven by exports of soybean and palm oil to Europe for use as animal feed, is a highly debated issue in Sweden and the European food sector (e.g. WWF 2014). As these emissions are currently untaxed, they should be included in a climate tax on food. The ISO 14067 standard states that emissions from LUC should be accounted for in a product's carbon footprint if they arise from a change in land management within a studied product system, i.e. from direct land use change (dLUC) (ISO 2013). Such emissions are normally allocated to the crops grown on the converted land
(Goglio et al. 2015). As opposed to dLUC, indirect land use change (iLUC) describes how an increase in production of a certain crop displaces other crops in an area. To keep up with demand for the displaced crop, production is moved to locations for which new and previously untilled land is cleared, causing GHG emissions (Röös and Nylinder 2013).

Various methods for accounting for emissions from LUC are available but give highly variable results, as the assessment, especially for iLUC, relies on several assumptions about the drivers of LUC (Finkbeiner 2014; Persson et al. 2014). Based on this, ISO 14067 states that iLUC emissions should be considered in climate impact assessments once international consensus has been reached (ISO 2013). However, none of the methods currently available for determining either dLUC or iLUC are generally accepted, and reaching consensus on methods will probably take considerable time, or may not even be possible, as choice of method reflects different perspectives on the problem (Flysjö et al. 2012).

Although the uncertainties in LUC calculations could favour exclusion of these emissions from a climate tax on food, we argue that for acceptance of a climate tax on food and because LUC emissions are currently untaxed, it is important to include the emissions in a tax. The LUC factors from Henders et al. (2015) are based on a method suggested by Persson et al. (2014) but updated with more recent data (Electronic Supplementary Material). The method takes both dLUC and iLUC into account by calculating the average emissions caused by LUC for a certain agricultural commodity and region (e.g. soybean from Brazil or palm oil from Indonesia), rather than allocating LUC emissions only to crops grown on recently deforested land. This method, apart from representing the latest developments in accounting for emissions from LUC, has an important advantage when using it for a tax; as LUC emissions are calculated on the 'average' commodity from a certain region, not just the crops grown on recently deforested land, it can be applied equally to all commodities from a certain region. That means that, e.g. all soybean from Brazil has the same LUC factor regardless of whether it is grown on newly deforested land or not (as long as deforestation driven by soybean cultivation continues in Brazil).

\subsubsection{Weighting emissions and tax levels of $\mathrm{CO}_{2}, \mathrm{CH}_{4}$ and $\mathrm{N}_{2} \mathrm{O}$}

To weigh the impact of different GHGs into one common unit, we use the Global Warming Potential over 100 years $\left(\mathrm{GWP}_{100}\right)$ according to the latest IPCC report (Myhre et al. 2013).

Using $\mathrm{GWP}_{100}$ is also the recommendation of the ISO 14067 standard (ISO 2013). The factors for $\mathrm{GWP}_{100}$ are available both with and without the effects of climate-carbon feedback mechanisms (Myhre et al. 2013). These take into consideration the effects of climate impact on changes in the climate cycle that can further amplify (or dampen) climate change. In our proposed method, the feedbacks are included 
based on the recommendations by UNEP/SETAC Life Cycle Initiative (2016). For $\mathrm{CH}_{4}, \mathrm{~N}_{2} \mathrm{O}$ and other non- $\mathrm{CO}_{2} \mathrm{GHGs}$, there is generally greater uncertainty in the metrics than for $\mathrm{CO}_{2}$ when including the feedback mechanisms (Levasseur et al. 2016). To test the sensitivity of including the feedback mechanisms, as well as of using metrics other than the $\mathrm{GWP}_{100}$ and taxing each gas separately, a sensitivity analysis was carried out (section 5.3).

\subsubsection{Summary of methodology used in the proposed method}

A summary of the methodology used in the proposed method is presented in Table 1. Factors for all methodological choices and those tested in the sensitivity analysis are presented in the Electronic Supplementary Material.

\section{Results}

The carbon footprint of a set of food groups on the Swedish market, calculated using the proposed method, is presented in Fig. 4. Results for other food groups are provided in the Electronic Supplementary Material, together with transparent results for all products divided over separate processes in the life cycle stages. The results were validated against existing datasets and studies; Fig. 4 provides a comparison with the values (median and variation intervals) in Clune et al. (2017) which is a compilation of published LCA studies on different foods, i.e. they come from different countries and are performed using different methodologies. The results are in line with the results reported by Clune et al. (2017), with plantbased foods and especially fruit and vegetables having a substantially lower carbon footprint than animal products, particularly ruminant meat. Using the method presented here gives higher carbon footprint for beef and dairy products than the median value in Clune et al. (2017) due to the use of the latest (and higher) characterisation factor for $\mathrm{CH}_{4}$ (34 instead of 25). The higher value here for grains is explained by accounting for waste along the chain and at retailer, which also partly explains why the carbon footprint for fruit and vegetables on the Swedish market is higher than the median values in Clune et al. (2017). For fruit and vegetables, longer transport distances also add to the discrepancy between the carbon footprints calculated here and the data in Clune et al. (2017).

\section{Discussion}

The simplified top-down method proposed here to calculate the carbon footprint of foods on the Swedish market showed to produce results in line with previous studies. At the same time, it fulfils the aim of being useful and robust for use for a climate tax on food in the following ways:

- The method is consistent as the same methodological choices are used across all food groups included.

- It produces carbon footprints of foods which is representative of foods on the Swedish market by accounting for food imports and production methods in different countries.

- The data and methodological choices are transparent, the method builds on publically available data and the full model including all data is made available.

However, in the development of this method, several unavoidable methodological choices had to be made. Therefore, in the 'Choice of system boundaries', 'Accounting for carbon changes in soils' and 'Weighting emissions and tax levels of $\mathrm{CO}_{2}, \mathrm{CH}_{4}$ and $\mathrm{N}_{2} \mathrm{O}$ ' sections, sensitivity analyses of the most important choices are presented to provide further justification of these choices. In the 'Limitations' section, general limitations of the method are discussed.

\subsection{Choice of system boundaries}

Figure 5 shows how the choice of system boundary affects the climate impact of an illustrative set of foods, using the system boundaries in Fig. 3 (for all food groups, see Electronic Supplementary Material). Limiting a climate tax on food to agricultural emissions of $\mathrm{CO}_{2}, \mathrm{CH}_{4}$ and $\mathrm{N}_{2} \mathrm{O}$ would exclude on average $46 \%$ of emissions for pork and $50 \%$ for chicken but only $18 \%$ for beef and $32 \%$ for milk (see Electronic Supplementary Material). Emissions from agriculture also dominate the climate impact of rice, due to high emissions of $\mathrm{CH}_{4}$ from flooded rice paddy fields. For plant-based foods

Table 1 Summary of the methodology used in the proposed method

\begin{tabular}{|c|c|c|c|c|c|c|}
\hline Type of LCA & Reference unit & $\begin{array}{l}\text { Allocation } \\
\text { method }\end{array}$ & System boundary & Changes in soil carbon & Emissions due to LUC & Weighting of GHGs \\
\hline ALCA & $\begin{array}{r}\text { Per } \mathrm{kg}^{\mathrm{a}} \text { or } \\
\text { per litre }\end{array}$ & Economic & $\begin{array}{l}\text { Cradle to retail gate } \\
\text { (including waste } \\
\text { through all stages } \\
\text { and at retailer) }\end{array}$ & $\begin{array}{l}\text { Included based on the } \\
\text { ICBM over } 100 \text { years } \\
\text { (Andrén and } \\
\text { Kätterer 1997) }\end{array}$ & $\begin{array}{l}\text { Included based on } \\
\text { method suggested by } \\
\text { Persson et al. (2014) }\end{array}$ & $\begin{array}{l}\mathrm{GWP}_{100} \text { with climate-carbon } \\
\text { feedbacks (Myhre } \\
\text { et al. 2013) }\end{array}$ \\
\hline
\end{tabular}

${ }^{\mathrm{a}}$ Per $\mathrm{kg}$ bone free weight for meat, per kg edible weight for fish and seafood 

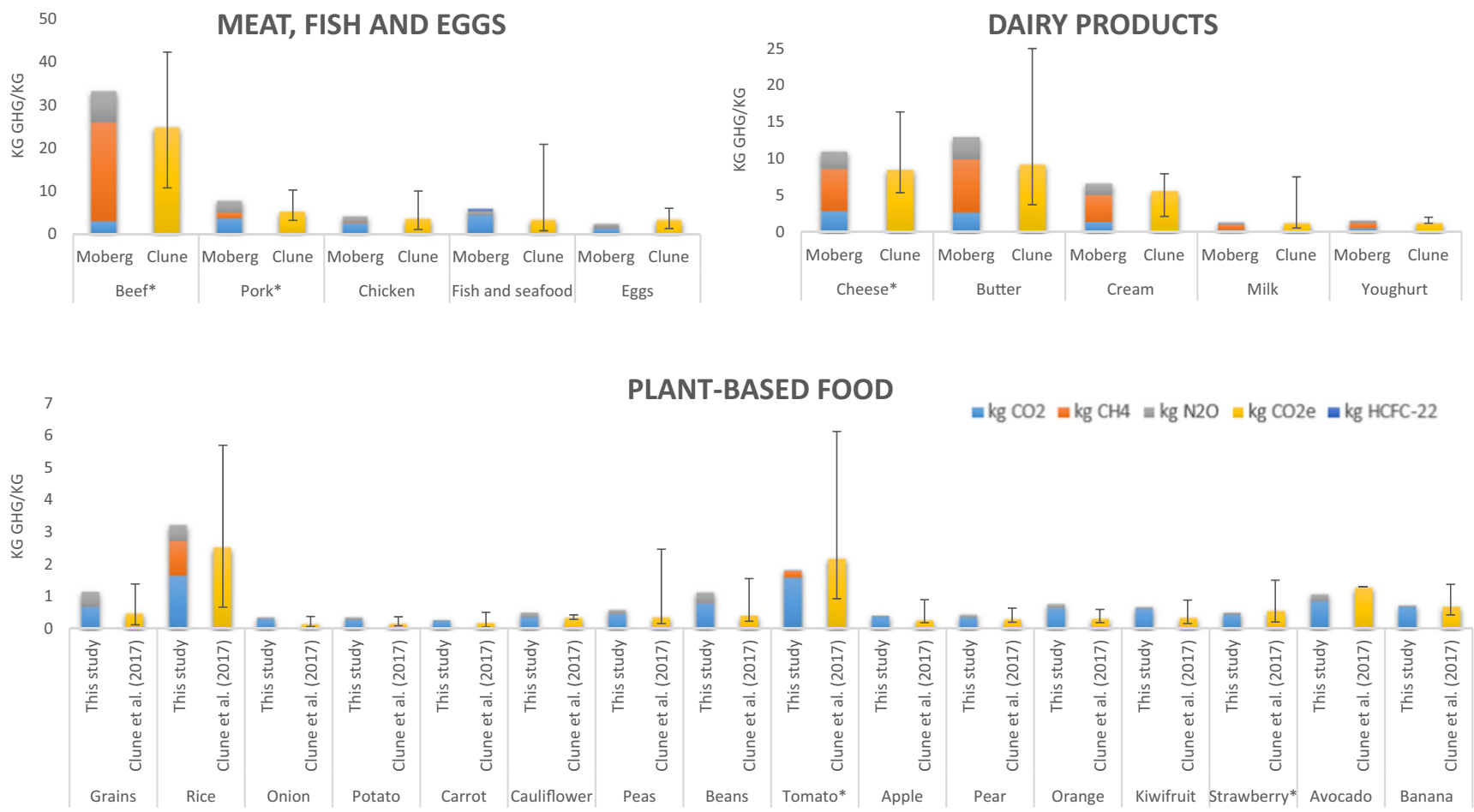

Fig. 4 Climate impact per $\mathrm{kg}$ of food (per $\mathrm{kg}$ bone free weight for meat and edible weight for fish) on the Swedish market from this study, validated to median values and variation intervals in Clune et al.

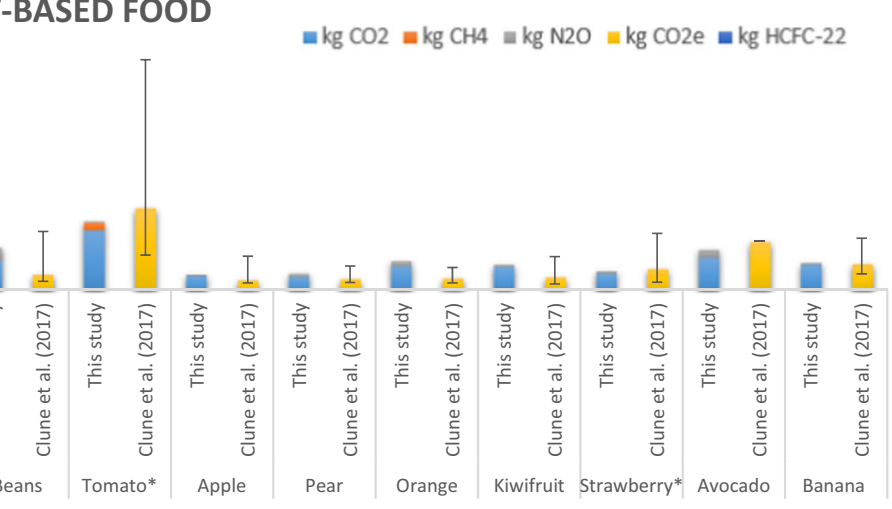

(2017). Beef and pork*: EU Average from Clune et al. (2017). Cheese*: average of hard and dessert cheese. Tomato*: only heated greenhouse. Strawberry*: only open-field

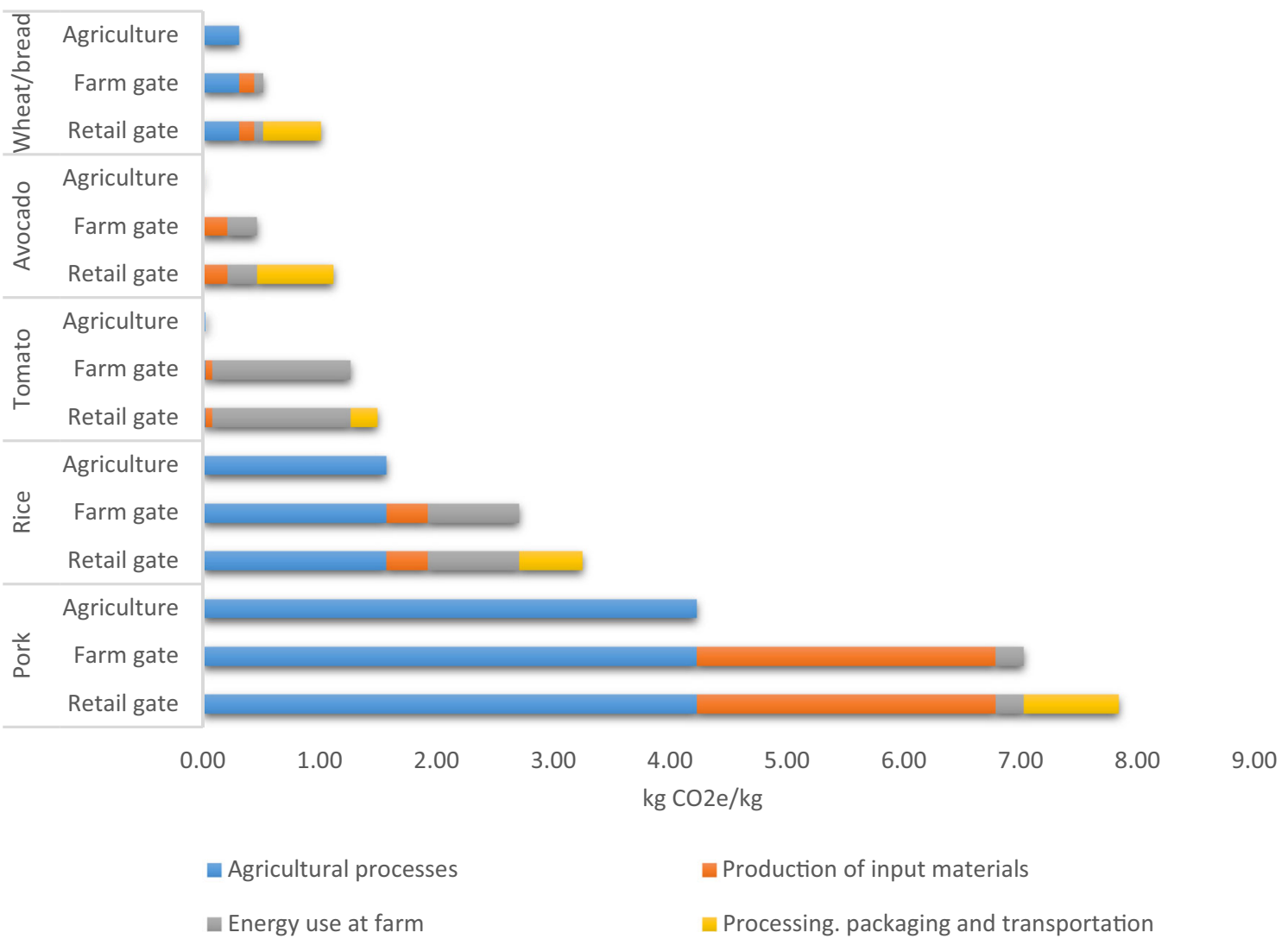

Fig. 5 Carbon footprint of a set of food products using different system boundaries 
grown in greenhouses on the other hand, e.g. tomatoes, emissions from energy use are a major contributor in the life cycle. For tomatoes, taxing only agricultural emissions or full cradleto-retail emissions would result in a very different tax.

As mentioned, taxing only agricultural emissions would probably be the easiest option with respect to administration. In addition, it would target emissions that are currently untaxed and avoid double taxation of products. However, it would risk excluding many of the emissions from e.g. plantbased foods, such as packaging, processing and transportation, which might lead to less understanding and acceptance of a tax as these processes are often perceived by consumers to have great influence on the overall climate impact (Shi et al. 2018). Thus, choosing to tax either up to farm gate or retail gate might gain more understanding and acceptance of a tax. Using set values for processes after farm gate, as suggested here ('General model choices and input data used in the modelling' section), would ease the administration and implementation of a tax from cradle to retailer.

In conclusion, the choice of system boundary for a tax involves a trade-off between ease of administration and accuracy of emission levels, where the latter is important for cost efficiency and acceptance.

\subsection{Accounting for carbon changes in soils}

The ICBM model used here to assess the 'soil carbon change potential' (section 3.3.5) requires input of regional data, which is lacking for many food production systems outside Sweden. The Tier 1 approach of the IPCC NIR guidelines for assessing soil carbon changes, on the other hand, is based on fixed factors for different levels of land management, tillage intensity and inputs of organic material (IPCC 2006). As the IPCC method is very simple and could be used consistently for foods from different world regions, we tested if this would be a suitable method for accounting for soil carbon changes. As in the ICBM approach, the 'soil carbon change potential', annualised over 100 years, was assessed from cultivation of $1 \mathrm{~kg}$ of cereals, legumes, oilseed rape, root vegetables and grass-clover ley. Figure 6 shows the results of the two different approaches for an illustrative set of food groups.

For ruminant products, the climate impact was expected to decrease due to the large proportion of grass in ruminant diets. The results from the ICBM modelling followed this assumption, with a decrease in the overall impact of beef by $5 \%$ and milk by 3\% (Fig. 6). When using the IPCC Tier 1 approach however, the climate impact of both products instead increased (Fig. 6), as the emission rates for annual crops used in ruminant diets exceeded the sequestration rate of ley (Electronic Supplementary Material). Hence, the IPCC approach failed to capture the sequestration potential of Swedish grass-clover leys that is well described in the literature (Poeplau et al. 2015), while the ICBM approach gave results in line with empirical data for the Nordic countries
(Kätterer et al. 2013). Hence, using the ICBM approach is a better choice in this case, although it might not correctly reflect the soil carbon changes associated with imported products. Due to the uncertainties in accounting for soil carbon changes, it could be argued that these emissions should be excluded in a climate tax on food. However, as accounting for soil carbon changes may substantially affect the carbon footprint of foods, we argue that including the emissions or sequestration in an uncertain way with average values is more accurate than excluding them entirely. As LCA studies neglecting to account for soil carbon have been criticised repeatedly by researchers (e.g. Stanley et al. 2018) and by proponents of grass-fed ruminant production (e.g. Rundgren and Bremen 2017), including soil carbon changes can be especially important for acceptance of a climate tax on food, as it decreases the difference between ruminant and monogastric meat.

A general limitation of both models is that it is far from certain that the emissions or sequestration of carbon attributed to different crops will actually take place (compared with $\mathrm{CH}_{4}$ emissions from enteric fermentation, which are known to take place), as the methods are based on average regional conditions rather than site-specific conditions. For example, much ruminant production takes place on soils that are already high in carbon, as cropping systems on these farms have been dominated by ley for a long time, and these soils therefore have limited potential for sequestering additional carbon. Conversely, many annual crops are cultivated on soils less rich in carbon and these soils would not emit as much carbon during cropping as 'average' carbon-rich soils.

\subsection{Weighting emissions and tax levels of $\mathrm{CO}_{2}, \mathrm{CH}_{4}$ and $\mathrm{N}_{\mathbf{2}} \mathrm{O}$}

As previously mentioned, excise taxes should in theory be designed according to the marginal damage and associated cost of the climate impact. The marginal damage cost can be set on separate GHGs (one price for $\mathrm{CO}_{2}$ emissions, one for $\mathrm{CH}_{4}$ emissions and so on) or on $\mathrm{CO}_{2} \mathrm{e}$ based on e.g. GWP $\mathrm{GW0}_{100}$ (Marten et al. 2015). Figure 7 shows the marginal damage cost using different approaches for weighting different GHGs: $\mathrm{GWP}_{100}$, the Global Temperature Potential for 100 years $\left(\mathrm{GTP}_{100}\right)$ (Myhre et al. 2013), i.e. based on the temperature change caused by the different gases in 100 years, and GTP factors based on Persson et al. (2015). Persson et al. (2015) argue that using a 100-year time horizon for GTP is not in line with the Paris agreement target to limit warming to $2{ }^{\circ} \mathrm{C}$, as this warming is expected to be reached within 100 years (at some point between 2050 and 2100). They therefore suggest using GTP corresponding to times when the target is expected to be met and to account for uncertainty in these timings. For GWP $\mathrm{GW0}_{100}$ and $\mathrm{GTP}_{100}$, the cost both with and without inclusion of climate-carbon feedbacks for $\mathrm{CH}_{4}$ and $\mathrm{N}_{2} \mathrm{O}$ is shown. Further, the marginal damage cost of separate GHGs based on the cost estimates by Marten et al. (2015) is applied. 
Fig. 6 Carbon footprint of a set of food products, with emissions and sequestration due to soil carbon changes calculated with the ICBM approach and with the IPCC Tier 1 approach

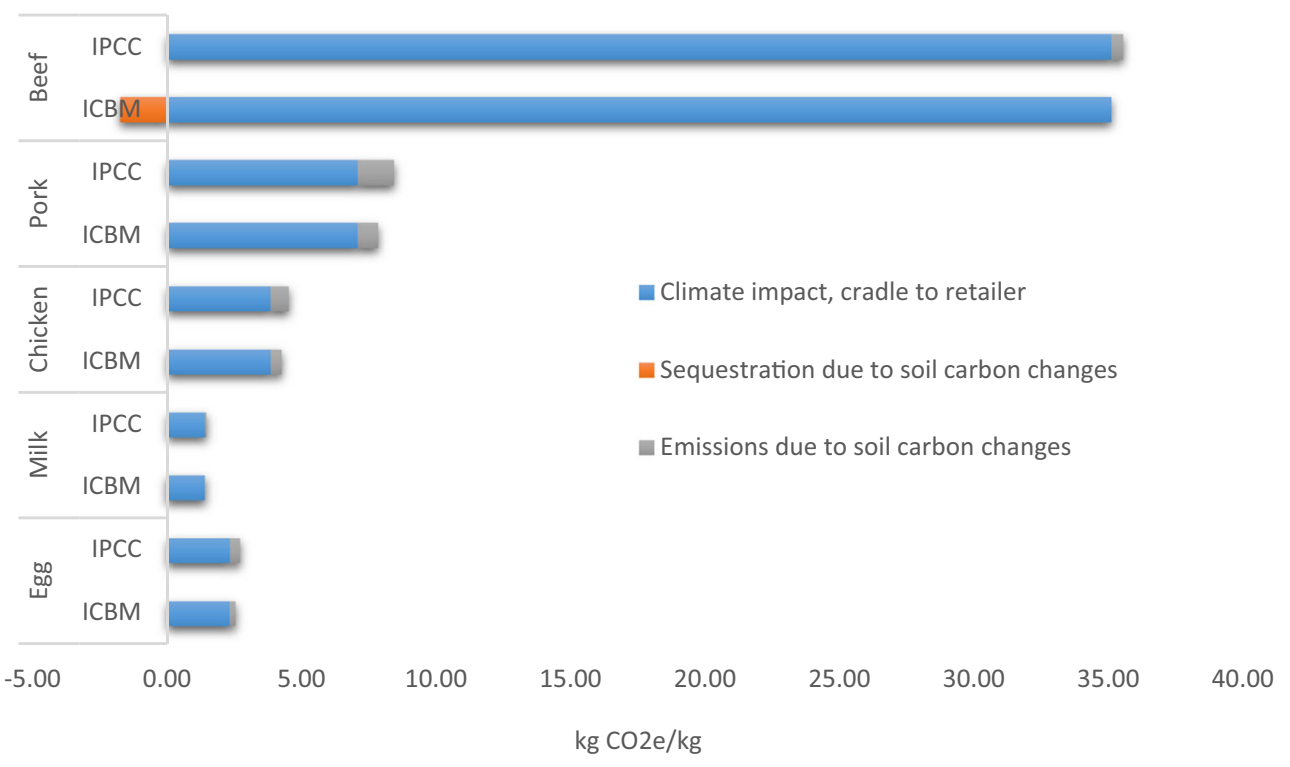

Differences in how the GHG emissions were weighted were most pronounced for beef, cheese and rice, whereas for other products such as potato, the different weighting approaches had minor effects. This is due to the large emissions of $\mathrm{CH}_{4}$ that arise from the production of these products and to the difference between the characterisation factors used for $\mathrm{CH}_{4}$. With the exception of rice, non-ruminant products generally cause more emissions of $\mathrm{CO}_{2}$ and $\mathrm{N}_{2} \mathrm{O}$, for which weightings according to different characterisation factors were quite similar (Electronic Supplementary Material). Including climate-carbon feedback increased the climate impact for all products, but the differences were more pronounced for products causing large emissions of $\mathrm{CH}_{4}$ (Fig. 7).

Implementing a tax based on the marginal damage cost of each separate GHG is argued to be most cost-efficient as an optimal climate tax should be differentiated between GHGs due to their different climate impact (Gren et al. 2019). Current climate reporting is however based on $\mathrm{GWP}_{100}$, why using $\mathrm{GWP}_{100}$ would be an advantage for acceptance and ease of administration. And as the difference between using $\mathrm{GWP}_{100}$ in taxation and taxing GHGs separately is small in most cases, as shown in Fig. 7, we choose to use $\mathrm{GWP}_{100}$ in the suggested method.

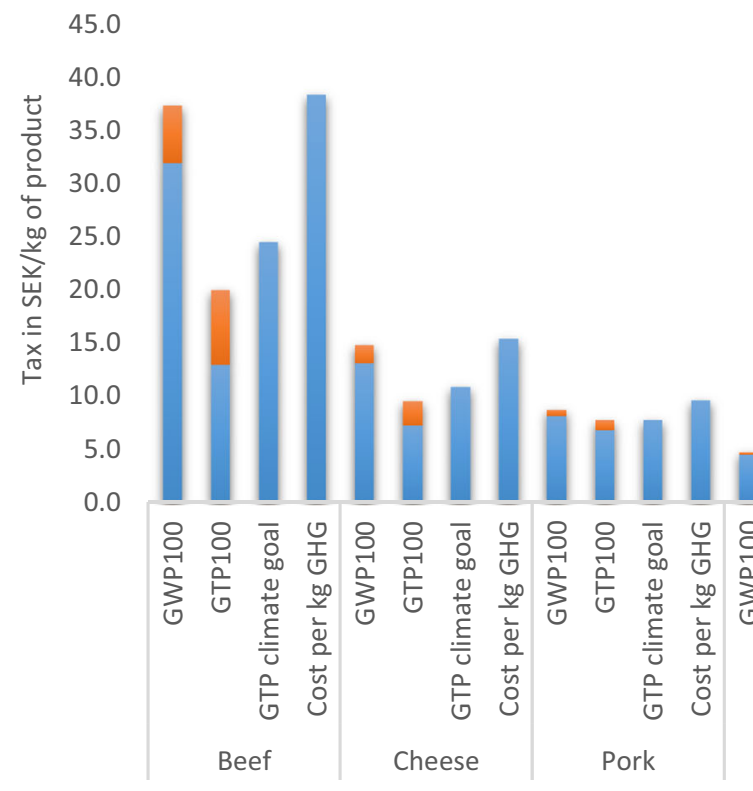

Fig. 7 Tax rates in SEK with different weighting of the climate impact and with/without inclusion of climate-carbon feedbacks. A social marginal cost is applied of $1120 \mathrm{SEK} / \mathrm{t}$ for $\mathrm{CO}_{2}, 35,797 \mathrm{SEK} / \mathrm{t}$ for $\mathrm{CH}_{4}$ and
Climate-carbon feedback

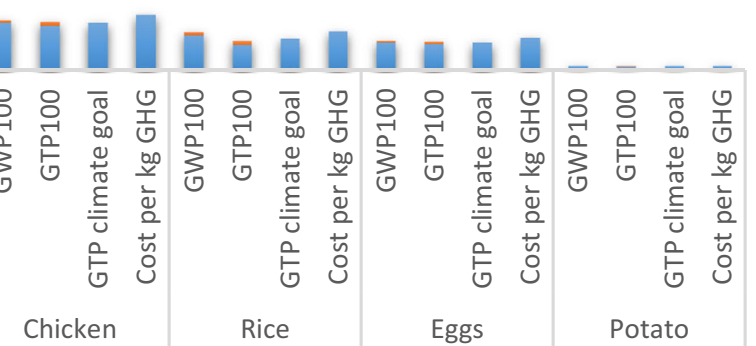

$438,762 \mathrm{SEK} / \mathrm{t}$ for $\mathrm{N}_{2} \mathrm{O}$, according to Marten et al. (2015). Prices in USD in Marten et al. (2015) are converted using the 2017 exchange rate 
Both GWP and GTP rely on an arbitrary choice of time horizon, often fixed to 100 years, which can affect climate mitigation priorities. Using GTP factors as suggested by Persson et al. (2015) would be a more accurate option in order for a tax to move towards an actual climate goal. However, using GWP ${ }_{100}$ for a climate tax would be more consistent with how climate policy is developed to date. Including climatecarbon feedbacks for all GHGs and not only $\mathrm{CO}_{2}$ in GWP factors would introduce a trade-off between consistency in the methodology and accuracy, due to the uncertainty of the calculations. As recommended by UNEP/SETAC Life Cycle Initiative (2016), our proposed method includes climatecarbon feedbacks, for consistency in calculations.

\subsection{Limitations}

The method suggested here to calculate the climate impact values has several limitations. It could be critiqued both for being overly complicated, including too many (unimportant) processes and requiring too much input data, e.g. for packaging and transports, and for being overly simplified, e.g. not distinguishing between different processing or packaging alternatives. The method is the result of a balancing act between completeness in order to be acceptable and 'correct' and simplicity in calculations and maintenance. Ultimately, how taxes are set is the result of political negotiations and compromises, the final result not always reflecting what is 'optimal' or 'correct'. The transparent method presented here can however provide valuable input to such discussions.

As for data availability, this is also a challenge for certain production countries, food groups and production systems, especially as regards agricultural statistics and data on regions outside Europe. For food groups such as fish and seafood, we were unable to find any official data on key parameters such as fuel use and landed catch of fishing vessels. Hence, for some products, input data for the present study had to be taken from the inventories in earlier LCA studies. However, ongoing initiatives in compiling databases for fish and seafood may facilitate future assessment (e.g. Parker et al. 2018). Tracing food trade is also a challenge; trade statistics may hide the true country of origin, which hinders country-specific assessments for some food products and assumptions regarding the export country have to be made.

Regarding the maintenance of the dataset, this can also be a challenge considering the amount of data that is required. However, input data on the most influential parameters can easily be updated on a regular basis, as these come from reports that are compiled by authorities for other purposes. For emission sources where there is limited data availability or where set values are used, updates can be made less frequently. Detailed suggestions for maintenance of datasets are presented in the Electronic Supplementary Material.

\section{Conclusions}

This paper presents transparent food carbon footprint values for use in a climate tax, established using a consistent methodology across the taxed food products. A condition in determining the datasets was that the tax had to be administratively simple and accepted by affected stakeholders. The climate impact values were established by primarily using official national data, which facilitates data collection and updating of the values. The climate impact of foods available on the Swedish market calculated with the suggested model was in line with values reported in earlier studies in the field.

A sensitivity analysis on different approaches to setting system boundaries revealed that limiting a climate tax on food to agricultural emissions of $\mathrm{CO}_{2}, \mathrm{CH}_{4}$ and $\mathrm{N}_{2} \mathrm{O}$ would target currently untaxed GHGs and avoid double taxation of $\mathrm{CO}_{2}$ emissions from energy and fuel use. However, it would impose a trade-off between ease of administration and accuracy of emission levels of food at the retailer, where the latter is important for cost efficiency and acceptance. Despite uncertainties in accounting for soil carbon changes, including these emissions is important for consistency with calculation methodology and acceptance of a tax, as they substantially affect the carbon footprint of foods and especially the relative difference between animal-based products. Modelling emissions from soil carbon changes using a site-dependent method can be an advantage to obtain results in line with empirical data. For weighting different GHGs, taxing each gas individually would be more cost-efficient, but using GWP $_{100}$ for a climate tax would be most in line with current climate reporting, which could improve acceptance and consistency.

Ultimately, how taxes are set is a political decision, but carbon footprint values of food determined using a consistent, simplified method are required in the process. This study presents values of the climate impact established with one such method and provides valuable insights into how methodological choices affect the carbon footprint values obtained and the implications for taxation. This is indispensable knowledge in the political process of establishing a climate tax on food.

Funding We thank the Swedish Environmental Protection Agency for funding this project.

Open Access This article is distributed under the terms of the Creative Commons Attribution 4.0 International License (http:// creativecommons.org/licenses/by/4.0/), which permits unrestricted use, distribution, and reproduction in any medium, provided you give appropriate credit to the original author(s) and the source, provide a link to the Creative Commons license, and indicate if changes were made.

Publisher's note Springer Nature remains neutral with regard to jurisdictional claims in published maps and institutional affiliations. 


\section{References}

Andrén O, Kätterer T (1997) ICBM: the introductory carbon balance model for exploration of soil carbon balances. Ecol Appl 7:12261236

Australian Government (n.d.) Carbon Farming Initiative methodologies. [Online] http://www.environment.gov.au/climate-change/ government/emissions-reduction-fund/cfi/indigenous-australians/ cfi-methodologies [Accessed March 2018]

Bähr CC (2015) Greenhouse gas taxes on meat products: a legal perspective. Transnat Environ Law 4:153-179

Baumol WJ, Oates WE (1988) The theory of environmental policy. Cambridge Univ, Press

Brandão M, Clift R, Cowie A, Greenhalgh S (2014) The use of life cycle assessment in the support of robust (climate) policy making: comment on "using attributional life cycle assessment to estimate climate-change mitigation...". J Ind Ecol 18:461-463

Bryngelsson D, Wirsenius S, Hedenus F, Sonesson U (2016) How can the EU climate targets be met? A combined analysis of technological and demand-side changes in food and agriculture. Food Policy 59: $152-164$

BSI (2008) Specification for the assessment of the life cycle greenhouse gas emissions of goods and services. The British Standards Institution

BSI (2012) PAS 2050-1:2012. Assessment of life cycle greenhouse gas emissions from horticultural products. Supplementary requirements for the cradle to gate stages of GHG assessments of horticultural products undertaken in accordance with PAS 2050. The British Standards Institution

Clune S, Crossin E, Verghese K (2017) Systematic review of greenhouse gas emissions for different fresh food categories. J Clean Prod 140: 766-783

Drewnowski A (2009) Defining nutrient density: development and validation of the nutrient rich foods index. J Am Coll Nutr 28:421S$426 \mathrm{~S}$

Durlinger B, Koukouna E, Broekema R, Van Paassen M, Scholten J (2017) Agri-footprint 4.0. Part 1: methodology and basic principles. Gouda, the Netherlands

Ecoinvent Centre (2018) Ecoinvent database version 3.5. Dübendorf, Switzerland: Swiss Centre for Life Cycle Inventories

Edenhofer O, Pichs-Madruga R, Sokona Y, Seyboth K, Matschoss P, Kadner S, Zwickel T, Eickemeier P, Hansen G, Schlömer S (2011) IPCC special report on renewable energy sources and climate change mitigation. Prepared by Working Group III of the Intergovernmental Panel on Climate Change. Cambridge Univ. Press, Cambridge

European Commission (2016) Product environmental footprint pilot guidance. Guidance for the implementation of the EU Product Environmental Footprint (PEF) during the Environmental Footprint (EF) pilot phase

European Parliament, E \& Cote U (2014) Regulation (EU) No 517/2014 of the European Parliament and of the Council of 16 April 2014 on fluorinated greenhouse gases and repealing regulation (EC) No 842/ 2006 Text with EEA relevance. Off J Eur Union 57:195-230

European Union (2009) Directive 2009/28/EC of the European Parliament and of the Council of 23 April 2009 on the promotion of the use of energy from renewable sources and amending and subsequently repealing Directives 2001/77/EC and 2003/30/EC. Off J Eur Union 5:2009

Finkbeiner M (2014) Indirect land use change - help beyond the hype? Biomass Bioenergy 62:218-221

Finnveden G, Hauschild MZ, Ekvall T, Guinée J, Heijungs R, Hellweg S, Köhler A, Pennington D, Suh S (2009) Recent developments in life cycle assessment. J Environ Manag 91:1-21
Florén B, Sund V, Krewer C, Angervall T (2015) Lätt att välja rätt Klimatdata för medvetna val av livsmedelsråvaror i storkök. SP Rapport 2015:47. SP Swedish Institute for Food and Biotechnology, Borås, Sweden

Flysjö A, Cederberg C, Henriksson M, Ledgard S (2012) The interaction between milk and beef production and emissions from land use change - critical considerations in life cycle assessment and carbon footprint studies of milk. J Clean Prod 28:134-142

Food SCP RT (2013) ENVIFOOD Protocol, Environmental Assessment of Food and Drink Protocol, European Food Sustainable Consumption and Production Round Table (SCP RT), Working Group 1, Brussels, Belgium

Författningssamling S (1994) Lag om skatt på energi. SFS 1994:1776

Garnett T, Mathewson S, Angelides P, Borthwick F (2015) Policies and actions to shift eating patterns: what works? Review of the evidence of the effectiveness of interventions aimed at shifting diets in more sustainable and healthy directions. London, UK: Food Climate Research Network, The University of Oxford and Chatham House, The Royal Institute of International Affairs

Goglio P, Smith WN, Grant BB, Desjardins RL, McConkey BG, Campbell CA, Nemecek T (2015) Accounting for soil carbon changes in agricultural life cycle assessment (LCA): a review. J Clean Prod 104:23-39

Government of Sweden (2009) Regeringens proposition 2009/10:41. Vissa punktskattefrågor med anledning av budget propositionen för 2010. Stockholm

Gren I-M, Moberg E, Säll S, Röös E (2019) Design of a climate tax on food consumption: examples of tomatoes and beef in Sweden. J Clean Prod 211:1576-1585

Guardian, The (2012) Tesco drops carbon-label pledge. The Guardian [Online] https://www.theguardian.com/environment/2012/jan/30/ tesco-drops-carbon-labelling [Accessed March 2018]

Hallström E, Davis J, Woodhouse A, Sonesson U (2018) Using dietary quality scores to assess sustainability of food products and human diets: a systematic review. Ecol Indic 93:219-230

Hartmann C, Siegrist M (2017) Consumer perception and behaviour regarding sustainable protein consumption: a systematic review. Trends Food Sci Technol 61:11-25

Henders S, Persson UM, Kastner T (2015) Trading forests: land-use change and carbon emissions embodied in production and exports of forest-risk commodities. Environ Res Lett 10:125012

IPCC (2006) 2006 IPCC guidelines for national greenhouse gas inventories. Intergovernmental Panel on Climate Change

ISO (2013) Greenhouse gases - carbon footprint of productsrequirements and guidelines for quantification and communication. International Organization for Standardization

Kätterer T, Bolinder M, Thorvaldsson G, Kirchmann H (2013) Influence of ley-arable systems on soil carbon stocks in Northern Europe and Eastern Canada. The role of grasslands in a green future: threats and perspectives in less favoured areas. Proceedings of the 17th Symposium of the European Grassland Federation, Akureyri, Iceland, 23-26 June 2013, 2013. Agricultural University of Iceland, pp 47-56

Kløverpris JH, Baltzer K, Nielsen PH (2010) Life cycle inventory modelling of land use induced by crop consumption. Int J Life Cycle Assess 15:90-103

Koch P, Salou T (2016) AGRIBALYSE®: Rapport MéthodologiqueVersion 1.3. November 2016. Ed ADEME. Angers, France

Levasseur A, Cavalett O, Fuglestvedt JS, Gasser T, Johansson DJ, Jørgensen SV, Raugei M, Reisinger A, Schivley G, Strømman A (2016) Enhancing life cycle impact assessment from climate science: Review of recent findings and recommendations for application to LCA. Ecol Indic 71:163-174

Lööv H, Andersson R, Ekman S, Wretling Clarin A, Frid G, Kättström H, Larsson B, Sjödahl M (2013) Hållbar köttkonsumtion-Vad är det? Hur når vi dit? Report 2013:1. Swedish Board of Agriculture 
Marten AL, Kopits EA, Griffiths CW, Newbold SC, Wolverton A (2015) Incremental $\mathrm{CH} 4$ and $\mathrm{N} 2 \mathrm{O}$ mitigation benefits consistent with the US Government's SC-CO2 estimates. Clim Pol 15:272-298

Myhre G, Shindell D, Bréon F-M, Collins W, Fuglestvedt J, Huang J, Koch D, Lamarque J-F, Lee D, Mendoza B, Nakajima T, Robock A, Stephens G, Takemura T, Zhang H (2013) Anthropogenic and natural radiative forcing. In: Stocker TF, Qin D, Plattner G-K, Tignor M, Allen SK, Boschung J, Nauels A, Xia Y, Bex V, Midgley PM (eds) Climate change 2013: the physical science basis. Contribution of working group I to the fifth assessment report of the intergovernmental panel on climate change. Cambridge Univ. Press, Cambridge

Nemecek T, Bengoa X, Lansche J, Mouron P, Riedener E, Rossi V, Humbert S (2015) Methodological Guidelines for the Life Cycle Inventory of Agricultural Products. World Food LCA Database (WFLDB), Quantis and Agroscope, Lausanne and Zurich

Nijdam D, Rood T, Westhoek H (2012) The price of protein: review of land use and carbon footprints from life cycle assessments of animal food products and their substitutes. Food Policy 37:760-770

Notarnicola B, Sala S, Anton A, McLaren SJ, Saouter E, Sonesson U (2017) The role of life cycle assessment in supporting sustainable agri-food systems: a review of the challenges. J Clean Prod 140: 399-409

Parker RW, Blanchard JL, Gardner C, Green C, Green BS, Hartmann K, Tyedmers PH, Watson RA (2018) Fuel use and greenhouse gas emissions of world fisheries. Nat Clim Chang 8:333

Persson UM, Henders S, Cederberg C (2014) A method for calculating a land-use change carbon footprint (LUC-CFP) for agricultural commodities - applications to Brazilian beef and soy, Indonesian palm oil. Glob Change Biol 20:3482-3491

Persson UM, Johansson DJ, Cederberg C, Hedenus F, Bryngelsson D (2015) Climate metrics and the carbon footprint of livestock products: where's the beef? Environ Res Lett 10:034005

Pigou AC (1920) The economics of welfare. McMillan, London

Poeplau C, Bolinder MA, Eriksson J, Lundblad M, Kätterer T (2015) Positive trends in organic carbon storage in Swedish agricultural soils due to unexpected socio-economic drivers. Biogeosciences 12:3241-3251

Röös E, Nylinder J (2013) Uncertainties and variations in the carbon footprint of livestock products. Swedish University of Agricultural Sciences

Rundgren G, Bremen AHMV (2017) Bättre för klimatet med fler betande köttdjur. Svenska Dagbladet [Online] https://www.svd.se/battre-forklimatet-med-fler-betande-kottdjur [Accessed March 2018]

Säll S, Gren M (2015) Effects of an environmental tax on meat and dairy consumption in Sweden. Food Policy 55:41-53

SEPA (2017) National Inventory Report Sweden 2017. Greenhouse gas emission inventories 1990-2015. Submitted under the United Nations Framework Convention on Climate Change and the Kyoto Protocol. Swedish Environmental Protection Agency. Stockholm, Sweden
Shi J, Visschers VH, Bumann N, Siegrist M (2018) Consumers' climateimpact estimations of different food products. J Clean Prod 172: 1646-1653

Smith P, Clark H, Dong H, Elsiddig E, Haberl H, Harper R, House J, Jafari M, Masera O, Mbow C (2014) Agriculture, forestry and other land use (AFOLU). In: Edenhofer $\mathrm{O}$ et al (eds) Climate change 2014: mitigation of climate Change. Contribution of working group III to the fifth assessment report of the intergovernmental panel on climate change. Cambridge Univ. Press, Cambridge, pp 813-922

Springmann M, Mason-D'Croz D, Robinson S, Wiebe K, Godfray HCJ, Rayner M, Scarborough P (2016) Mitigation potential and global health impacts from emissions pricing of food commodities. Nat Clim Chang 7:69-74

Springmann M, Clark M, Mason-D'Croz D, Wiebe K, Bodirsky BL, Lassaletta L, De Vries W, Vermeulen SJ, Herrero M, Carlson KM (2018) Options for keeping the food system within environmental limits. Nature 562:519-525

SSNC (2015) Det subventionerade köttet - Finansiera ekosystemtjänster i jordbruket med en klimatavgift på kött. Swedish Society for Nature Conservation

Stanley PL, Rowntree JE, Beede DK, Delonge MS, Hamm MW (2018) Impacts of soil carbon sequestration on life cycle greenhouse gas emissions in Midwestern USA beef finishing systems. Agric Syst 162:249-258

Statistics Sweden (2018) Statistical database. Enterprise unit—basic data enterprises according to Structural Business Statistics by NACE Rev. 2. Year 2000-2016 [Online] http://www.statistikdatabasen. scb.se/pxweb/en/ssd/?rxid=0cc9b377-12ac-499d-aade5eef92e49e9e [Accessed Oct 2018]

Svensk Dagligvaruhandel (2018) Om branschen [Online] https://www. svenskdagligvaruhandel.se/om-oss/om-branschen/ [Accessed Oct 2018]

Swedish Tax Agency (n.d.) Punktskatter [Online] https://www. skatteverket.se/foretagochorganisationer/skatter/punktskatter.4. 71004e4c133e23bf6db800057013.html [Accessed March 2018]

UNEP/SETAC Life Cycle Initiative (2016) Global guidance for life cycle impact assessment indicators. United Nations Environment Programme

Van Doorslaer B, Witzke P, Huck I, Weiss F, Fellmann T, Salputra G, Jansson T, Drabik D, Leip A (2015) An economic assessment of GHG mitigation policy options for EU agriculture. EcAMPA vol Report EUR

Vermeulen SJ, Campbell BM, Ingram JS (2012) Climate change and food systems. Annu Rev Environ Resour 37:195-222

World Bank, Ecofys \& Vivid Economics (2016) State and trends of carbon pricing. Washington, DC, United States: World Bank

WWF (2014) Soy Report Card-Assessing the Use of Responsible Soy for Animal Feed in Europe. World Wildlife Fund, Gland

Ziegler F, Winther U, Hognes ES, Emanuelsson A, Sund V, Ellingsen H (2013) The carbon footprint of Norwegian seafood products on the global seafood market. J Ind Ecol 17:103-116 